\title{
Determination of antibacterial activity of essential oils from mint (Mentha spicata) leaves on selected pathogenic bacteria
}

\author{
Benson Muriuki Githaiga ${ }^{2}$, Eliud Mugu Gathuru² ${ }^{2}$ Paul Njenga Waithaka ${ }^{1^{\star}}$ and Lucy W. Kiarie ${ }^{2}$ \\ ${ }^{1}$ School of Biological Sciences, University of Nairobi, P. O. Box 30197 Nairobi, Kenya. \\ ${ }^{2}$ Department of Biological Sciences, Egerton University, P. O. Box 536, Njoro, Kenya. \\ *Corresponding author. Email: waithakanj@gmail.com. Tel: +254721104637.
}

Copyright (C) 2018 Githaiga et al. This article remains permanently open access under the terms of the Creative Commons Attribution License 4.0, which permits unrestricted use, distribution, and reproduction in any medium, provided the original work is properly cited.

Received 22nd September, 2018; Accepted 18th October, 2018

\begin{abstract}
Drug resistant pathogenic microorganisms account for the highest proportion of death today. This study was aimed at extracting essential oils (EOS) from mint. Sensitivity tests of selected pathogenic microorganism were also carried out. EOS were extracted using distillation method. Phytochemical screening of the essential oils for the presence of tannins, alkaloids, glycosides, flavonoids, resins, phenols and steroids was carried out using standard procedures. Sensitivity test of Staphylococcus aureus (ATCC 25923), Klebsiella pneumoniae (clinical isolate), Escherichia coli ((ATCC 25922), Erwinia carotovora (ATCC 33244), Xanthomonas campestris (ATCC 33913) and Bacillus subtilis (ATCC 6633) to the EOS was carried out using agar well diffusion technique. The minimum inhibitory concentration of the test pathogens by the essential oils was carried out using two-fold serial dilution. The yield of essential oils varied from $1.0 \pm 0.01 \%$ in first replicate to $3.0 \pm 0.03 \%$ in the fourth replicate. All the tested phytochemical compounds were present in the EOS of mint. There was no significant difference between the zones of inhibition of the three replicates $(F=0.34 P=0.74)$. In addition, there was no significant difference between the MIC's of the three replicates ( $F=0.33 P=0.72)$. Mint from Egerton University has EOS that can be extracted using distillation method. The EOS were bioactive against the selected bacterial pathogens which creates a need for their mass production.
\end{abstract}

Keywords: Egerton, sensitivity, pathogenic bacteria.

\section{INTRODUCTION}

In recent years, multiple drugs resistance has developed due to indiscriminate use of existing antimicrobial drugs in treatment of infectious diseases (Zaidi and Dahiya, 2015). In addition, these antibiotics are sometimes associated with adverse effects in their hosts. This creates a need for alternative antibiotic medicines for the treatment of infectious diseases from other sources such as plants (Huang et al., 2014). Natural products of higher plants may be a new source of antibiotic agents possibly with novel mechanism of action (Sonam et al., 2017).

Antibiotic resistance is one of the most serious health threats that result from selective pressure exerted by antibiotic misuse and abuse (Winanda et al., 2016). The problem has prompted researchers into identification of new biocide with broad spectrum of activity to control these pathogenic bacteria. Traditionally, EOS were used in folk medicine to extend the shelf life of foods. They were also used for treatment of minor ailments besides showing a cooling effect when used on muscle pain nerve relief (Bajera et al., 2017). Plants produce enormous array of functional relevant secondary metabolites (phytochemical) which exhibit diversity of medicinal properties (De Sousa et al., 2015). EOS from several plant species are able to control microorganisms related to skin, dental carries and food spoilage including both gram positive and gram negative bacteria (Diao et al., 2014).

Mint is widely used in food, cosmetics and in pharmaceutical industry (Knezevic et al., 2016). It is chemo 
preventive and anti-mutagenic (Ceylan et al., 2014). It has been proven helpful in symptomatic relief of common cold. It also decreases symptoms of irritable bowel syndrome and decrease digestive symptoms such as dyspepsia and nausea. In addition, it is used topically as an analgestic and to treat headache (Hua et al., 2017). It is mosquito repellent and has anti-nematodal, antiviral, antifungal properties (Lan et al., 2016). Thus, the aim of this study was to extract and determine the sensitivity of selected pathogenic bacteria to EOS from mint.

\section{MATERIALS AND METHODS}

\section{Study area}

Egerton University Main Campus is located 180 kilometers North West of Nairobi and about 30 Kilometers from Nakuru. The University lies on a 144 hectare piece of land donated by Lord Maurice Egerton of Tatton (1874 - 1958). The coordinates of the University are: $0^{\circ} 22^{\prime} 11.0 " \mathrm{~S}$, 355'58.0"E (Latitude: -0.369734; Longitude: 35.932779). The University lies at an altitude of approximately 2,250 meters above sea level (GoK, 2014).

\section{Collection of plant sample}

Mint (Mentha spicata) leaves were collected by hand picking from field 7 in Egerton University. The leaves were placed in new sterile polythene bags and transported to Department of Biological Sciences Laboratories, Egerton University, Njoro, Kenya. The samples were stored in refrigerated conditions at $4^{\circ} \mathrm{C}$ awaiting processing.

\section{Extraction of EOS}

Extraction of EOS was carried out using steam distillation method (Martuccia et al., 2015). A sample of $400 \mathrm{~g}$ of fresh mint leaves were loaded into 2-litre round bottom flask containing 1.5 litres of water and placed on a heating mantle having a power rating of 450 watts and timed (Figure 1). The samples were boiled with water to release the oil held within the matrix of leaves. The volatile oils evaporated along with the water into the condenser connected to the flask at $100^{\circ} \mathrm{C}$. The condensed steam and oils were collected in a separating funnel where the essential oil and water were separated. The water was drained off gently and the oils collected in a $10 \mathrm{~mL}$ measuring cylinder and measured. The measurements were recorded at an interval of 15 minutes for $1 \mathrm{~h}$ (Nikoli'c et al., 2014).

\section{Phytochemical screening of the EOS}

The presence or absence of the phytochemical constituents in the EOS was analysed using standard procedures for tannins, alkaloids, glycosides, flavonoids, resins, phenols and steroids as described by Rajinder et al. (2015).

\section{Test for tannins}

About $0.5 \mathrm{~mL}$ of the essential oils was dissolved in $1 \mathrm{ml}$ of water. Two drops of ferric acid solution were added. A blue or green blue colour indicated a positive test (Zhang et al., 2016).

\section{Test for alkaloids}

About $2 \mathrm{~mL}$ of the essential oils were dissolved in $2 \mathrm{~mL}$ of $2 \% \mathrm{HCL}$ and heat in a water bath for 10 minutes. Five drops of Meyer's reagent were added to the filtrate of the crude extract. Observation for appearance of turbidity was done (Yang et al., 2018).

\section{Test for glycosides}

To $2 \mathrm{~mL}$ of the essential oils, $1 \mathrm{~mL}$ of glacial acetic acid was added followed by few drops of ferric chloride and concentrated sulphuric acid. Observation for appearance of red brown indicated positive results (Sfeir et al., 2014).

\section{Test for flavonoids}

To $2 \mathrm{~mL}$ of the essential oils, few drops of concentrated $\mathrm{HCL}$ and $\mathrm{Mg}$ ribbon was added. Appearance of pink tomato red colour indicated a positive test (Yang et al., 2018).

\section{Test for resins}

To $1 \mathrm{~mL}$ of the essential oils, $1 \mathrm{~mL}$ of distilled water was added. Presence of turbidity indicated positive results (Costa et al., 2015).

\section{Test for phenols}

The essential oils were heated with 4 drops of alcoholic ferric chloride solution. Formation of a blue black or green colour indicated a positive test (Yang et al., 2018).

\section{Test for Steroids}

About $1 \mathrm{~mL}$ of the essential oils was dissolved in $5 \mathrm{~mL}$ chloroform. An equal amount of concentrated sulphuric acid was added from the side of the test tube. For positive 


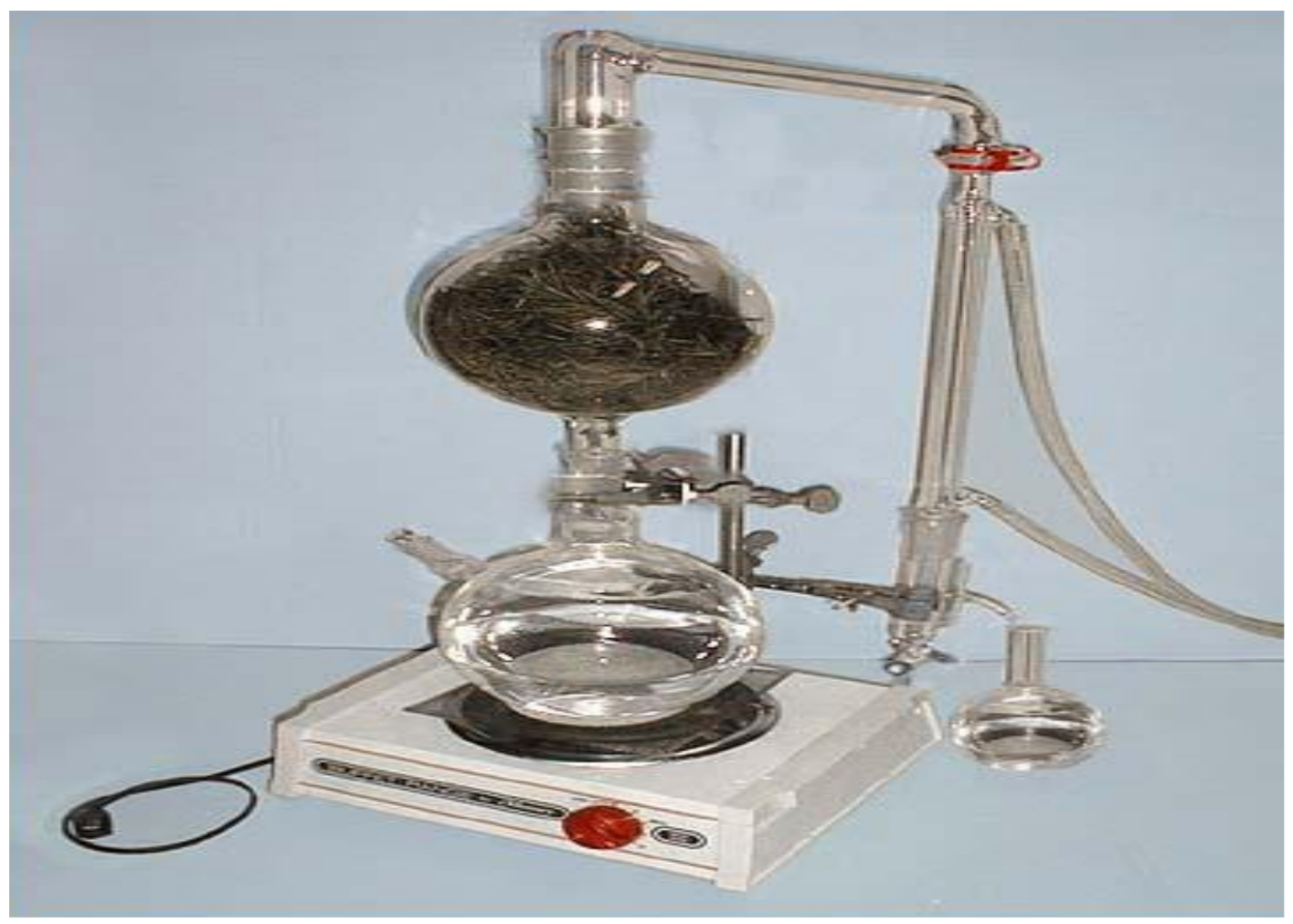

Figure 1. Essential oil distiller.

results, the upper layer turns red and sulphuric acid layer turns yellow with a green fluorescence (Radelli et al., 2015).

\section{Test pathogens}

The following test pathogens were used in the study such as Bacillus subtilis (ATCC 6633), Staphylococcus aureus (ATCC 25923), Klebsiella pneumoniae (clinical isolate), Escherichia coli (ATCC 25922), Erwinia carotovora (ATCC 33244) and Xanthomonas campestris (ATCC 33913).

\section{Preparation of standard inoculum}

The test pathogens were inoculated into Muller Hinton Broth (MHB) supplemented with $5 \%$ of sheep blood. Incubation was carried out at $37^{\circ} \mathrm{C}$ for $15 \mathrm{~h}$. The turbidity of the resulting suspension was diluted with MHB to match McFarland standard (Zhang et al., 2017).

\section{Determination of antibacterial activity}

The antibacterial activity of essential oils from mint leaves was determined using agar well diffusion method. Sterile Muller Hinton Agar was separately inoculated with the test pathogens using spread plate technique. Wells of $8 \mathrm{~mm}$ diameter were made in the agar with a cork borer and filled with the essential oils. Incubation was carried out at $37^{\circ} \mathrm{C}$ for $24 \mathrm{~h}$. The diameter of zones of inhibition was determined in $\mathrm{mm}$ using a ruler. Distilled water was used as negative control while $10 \mathrm{\mu g} \mathrm{ml}^{-1}$ vancomycin was used as positive control (Yang et al., 2018).

\section{Minimum inhibitory concentration}

Minimum inhibitory concentration was determined by twofold serial dilution method. About $1 \mathrm{~mL}$ of sterile Mueller Hinton Broth was placed in 11 sterile test tubes. Using a micropipette, $1 \mathrm{ml}$ of the mint EOS was placed in the second test tube. Serial dilution was carried out up to the 11th test tube. $0.1 \mathrm{~mL}$ of the standardized pathogens were separately added from the $1 \mathrm{st}$ test tube up to the 10th test tube. The 1st test tube was used as the negative control and the 11th test tube as the positive control. Incubation was carried out at $37^{\circ} \mathrm{C}$ for $24 \mathrm{~h}$. Growth was observed by visual inspection and by measuring optical density (OD) at $630 \mathrm{~nm}$ using a spectrophotometer after the visual reading (Sonam et al., 2017).

\section{Statistical analysis}

Data was presented using frequency tables. The relationship between time and yield of EOS was 
Table 1. Percentage yield of essential oils from mint.

\begin{tabular}{cccccc}
\hline Replicate & weight & Distilled water(L) & Heating time (Min) & Temperature $\left({ }^{\circ} \mathbf{C}\right)$ & Yield $(\%)$ \\
\hline 1 & 100 & 1 & 15 & 100 & $1.0 \pm 0.01$ \\
2 & 200 & 1 & 30 & 100 & $1.5 \pm 0.02$ \\
3 & 300 & 1 & 45 & 100 & $2.5 \pm 0.01$ \\
4 & 400 & 1 & 60 & 100 & $3.0 \pm 0.03$ \\
\hline
\end{tabular}

Table 2. Phytochemical compounds of essential oils from mint.

\begin{tabular}{clc}
\hline S. No & Test & Present/absent \\
\hline 1 & Tannins & + \\
2 & Alkaloids & + \\
3 & Glycosides & + \\
4 & Flavonoids & + \\
5 & Resins & + \\
6 & Polyphenols & + \\
7 & Steroids & + \\
\hline
\end{tabular}

Table 3. Sensitivity tests of bacterial pathogens to mint essential oils.

\begin{tabular}{lccc}
\hline \multirow{2}{*}{ Pathogen } & \multicolumn{3}{c}{ Zone of inhibition (mm) } \\
\cline { 2 - 4 } & Replicate 1 & Replicate 2 & Replicate 3 \\
\hline Staphylococcus aureus & $18 \pm 0.01$ & $16 \pm 0.02$ & $17 \pm 0.01$ \\
Escherichia coli & $15 \pm 0.02$ & $13 \pm 0.02$ & $14 \pm 0.01$ \\
Erwinia carotovora & $14 \pm 0.01$ & $14 \pm 0.02$ & $14 \pm 0.01$ \\
Bacillus subtilis & $18 \pm 0.02$ & $16 \pm 0.02$ & $17 \pm 0.01$ \\
Xanthomonas campestris. & $23 \pm 0.01$ & $20 \pm 0.02$ & $22 \pm 0.01$ \\
Klebsiella pneumoniae & $20 \pm 0.02$ & $20 \pm 0.02$ & $20 \pm 0.01$ \\
\hline
\end{tabular}

$\mathrm{F}=0.34 \mathrm{P}=0.74$.

determined using Pearson Correlation. The means of sensitivity test and minimum inhibitory concentrations were compared using ANOVA.

\section{RESULTS}

\section{Yield of EOS from mint}

The yield of essential oils varied from $1.0 \pm 0.01 \%$ in the first replicate to $3.0 \pm 0.03 \%$ in the fourth replicate (Table 1 ). The heating time ranged from 15 minutes to 60 minutes. There was a relationship between heating period and yield of essential oils $(r>1)$.

\section{Phytochemical screening of essential oils from mint extracts}

The results on phytochemical tests of the extracts are presented in Table 2. All the tested phytochemical compounds were present in the essential oils of mint.

\section{Antibacterial activity}

The zones of inhibition in $S$. aureus varied from $16 \pm 0.02$ $\mathrm{mm}$ in replicate 2 to $18 \pm 0.01 \mathrm{~mm}$ in replicate 1 , E. coli $(13 \pm 0.02 \mathrm{~mm}$ in replicate 2 to $15 \pm 0.02 \mathrm{~mm}$ in replicate 1$)$, E. carotovora $(14 \pm 0.01 \mathrm{~mm}$ in replicate 1 and 3 to $14 \pm 0.02$ $\mathrm{mm}$ in replicate 2$), B$. subtilis $(16 \pm 0.02 \mathrm{~mm}$ in replicate 2 to $18 \pm 0.02 \mathrm{~mm}$ in replicate 1$), X$. campestris $(20 \pm 0.02 \mathrm{~mm}$ in replicate 2 to $23 \pm 0.01 \mathrm{~mm}$ in replicate 1 ) and in $K$. pneumoniae $(20 \pm 0.01 \mathrm{~mm}$ in replicate 3 to $20 \pm 0.02 \mathrm{~mm}$ in replicate 1 and 2) (Table 3). There was no significant difference between the zones of inhibition of the three replicates ( $\mathrm{F}=0.34 \mathrm{P}=0.74)$ (Figure 2$)$.

\section{Minimum inhibition concentration of the EOS from mint}

The minimum inhibitory concentration in $S$. aureus varied from $0.3 \pm 0.02 \mathrm{mg} / \mathrm{mL}$ in replicate 2 to $0.4 \pm 0.02 \mathrm{mg} / \mathrm{mL}$ in replicate 1 , E. coli $(0.4 \pm 0.02 \mathrm{mg} / \mathrm{Ml}$ in replicate 2 to $0.5 \pm 0.02 \mathrm{mg} / \mathrm{mL}$ in replicate 3$)$, E. carotovora $(0.5 \pm 0.01$ 


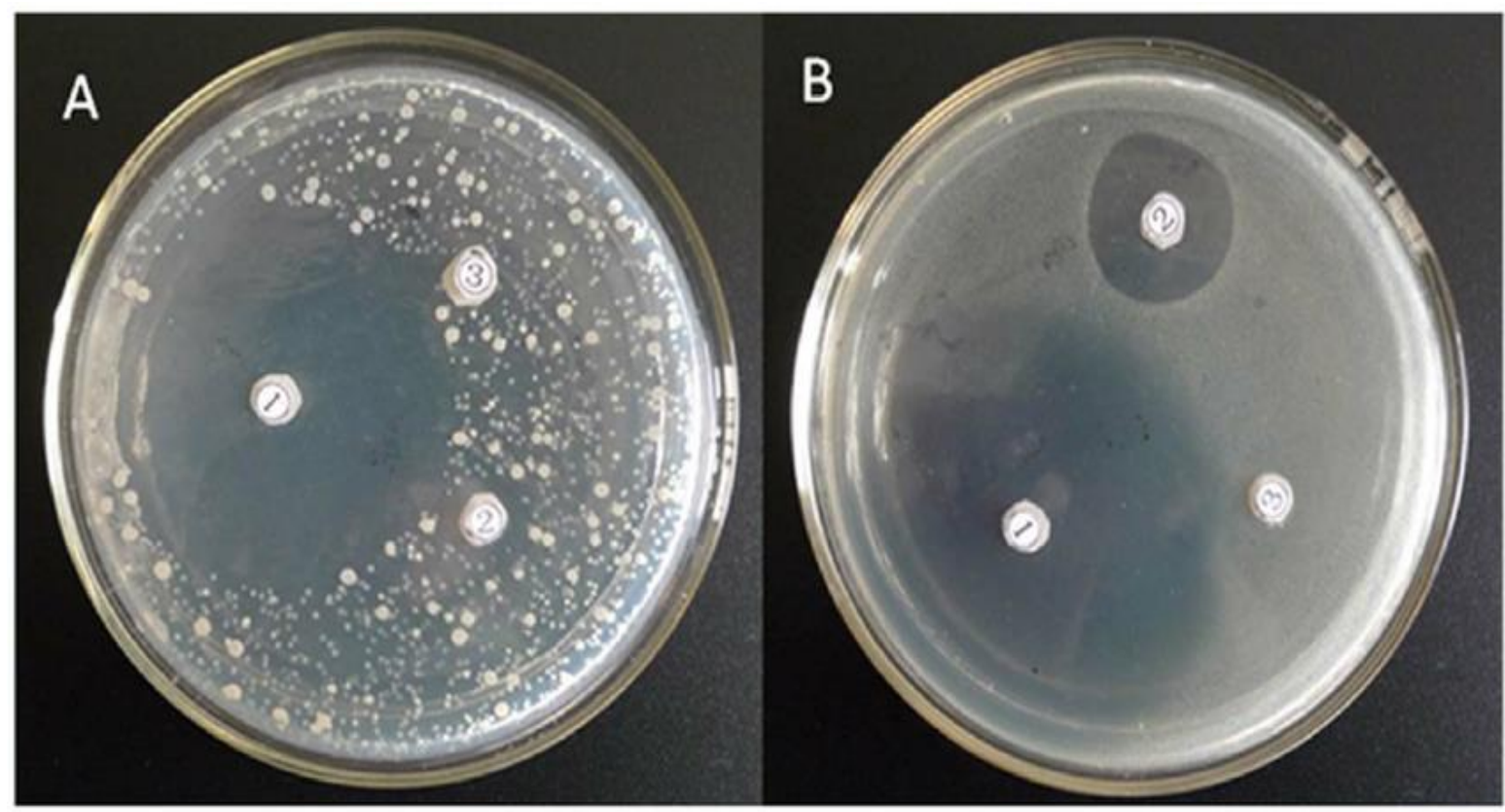

Figure 2. Zones of inhibition for Staphylococcus (A) and E. coli (B).

Table 4. Minimum Inhibitory Concentration (MIC) of essential oils from mint when tested against selected bacterial pathogens.

\begin{tabular}{lccc}
\hline \multirow{2}{*}{ Type of bacteria } & \multicolumn{3}{c}{ MIC (mg/ml) } \\
\cline { 2 - 4 } & Replicate 1 & Replicate 2 & Replicate 3 \\
\hline Staphylococcus aureus & $0.4 \pm 0.02$ & $0.3 \pm 0.02$ & $0.4 \pm 0.01$ \\
Escherichia coli & $0.5 \pm 0.01$ & $0.4 \pm 0.02$ & $0.5 \pm 0.02$ \\
Erwinia carotovora & $0.5 \pm 0.01$ & $0.5 \pm 0.01$ & $0.5 \pm 0.02$ \\
Bacillus subtilis & $0.7 \pm 0.02$ & $0.6 \pm 0.02$ & $0.6 \pm 0.01$ \\
Xanthomonas campestris & $0.4 \pm 0.02$ & $0.4 \pm 0.02$ & $0.5 \pm 0.02$ \\
Klebsiella pneumoniae & $0.3 \pm 0.01$ & $0.4 \pm 0.01$ & $0.4 \pm 0.01$ \\
\hline
\end{tabular}

$\mathrm{F}=0.33 \mathrm{P}=0.72$.

$\mathrm{mg} / \mathrm{mL}$ in replicate 1 and 2 to $0.5 \pm 0.02 \mathrm{mg} / \mathrm{mL}$ in replicate $3), B$. subtilis $(0.6 \pm 0.01 \mathrm{mg} / \mathrm{mL}$ in replicate 3 to $0.7 \pm 0.02$ $\mathrm{mg} / \mathrm{mL}$ in replicate 3$), X$. campestris $(0.4 \pm 0.02 \mathrm{mg} / \mathrm{ML}$ in replicate 1 and $2-0.5 \pm 0.02 \mathrm{mg} / \mathrm{mL}$ in replicate 3 ) and in $K$. pneumoniae $(0.3 \pm 0.01 \mathrm{mg} / \mathrm{ML}$ in replicate 1 to $0.4 \pm 0.01$ $\mathrm{mg} / \mathrm{mL}$ in replicate 2 and 3) (Table 4). There was no significant difference between the MICs of the three replicates $(\mathrm{F}=0.33 \mathrm{P}=0.72)$.

\section{DISCUSSION}

The induction period for extraction of essential oils was between 0 to 15 minutes. Induction period, is the time required to rupture the cells of the plant material in order to release the oil and transport it to the condenser (Si et al., 2016). The yield of essential oil increased with time.
These results agreed with a previous study carried out in Brazil (Radaelli et al., 2015). The similarity in results in the two studies may have been caused by the two studies being carried out in similar environments (Babar et al., 2015).

However, the results of this study demonstrated that the essential oils from mint were dominated by tannins, alkaloids, glycosides, flavonoids, resins, phenols and steroids. This was contrary to findings by Plant and Stephens (2015), since flavonoids and steroids were absent in the latter study. The difference in results may have originated from differences in soil physicochemical characteristics which the plants were growing in. According to El Babili et al. (2014), the soil constituents influence the phytochemical accumulated by mint.

The antibacterial activity of mint was assessed using agar well diffusion method by measuring the diameter of 
growth inhibition of the test pathogens by the essential oils from mint (Hercules and Chrissanthy, 2017). Gram positive bacteria are known to be more susceptible to essential oils than gram negative due to variation in the structure of the cell wall (Lang and Buchbauer, 2012). However, the results of this study differed with this observation since there was no significant difference in the zones of inhibition between gram positive and gram negative bacteria (Freires et al., 2015). These results disagreed with a previous study by Aishwarya (2015). This may have arisen from differences in the composition in the essential oils produced by the plant samples (de Aguiar et al., 2018).

However, the minimum inhibitory concentrations of the essential oils obtained in the current study (Table 4) partially agreed with a study carried out in Mauritius (Aumeeruddy-Elalfi et al., 2015). This may have been caused by similarity of the active ingredients of the essential oils in the two studies. In addition, Shaaban et al. (2014) asserted that strains of the test pathogens under investigation influence the minimum inhibitory concentration of an antibiotic. Huerta et al. (2016) attributed minimum inhibitory concentration of essential oils from mint to the evolutionary stage of test pathogens.

\section{Conclusions}

Mint from Egerton University has essential oils that can be extracted using distillation method. The essential oils inhibited growth of the selected bacterial pathogens.

\section{Recommendations}

The essential oils from mint should be extracted in large scale. There is need to determine the mechanism through which the essential oils inhibit growth of pathogenic microorganisms. In addition, sensitivity test of fungal pathogens to the essential oils need to be carried out.

\section{CONFLICT OF INTEREST}

The authors declare no conflict of interest.

\section{ACKNOWLEDGEMENT}

Thanks to the Department of Biological Sciences, Egerton University for giving us laboratory space for carrying out the study.

\section{REFERENCES}

Aishwarya, B. (2015). Therapeutic uses of peppermint -A Review. Journal of Pharmaceutical Science and Research, $7(7), 474-476$.
Aumeeruddy-Elalfi, Z., Gurib-Fakim, A., \& Mahomoodally, F. (2015). Antimicrobial, antibiotic potentiating activity and phytochemical profile of essential oils from exotic and endemic medicinal plants of Mauritius. Indian Crops Production, 71, 197-204.

Babar, A., Naser, A. A., Saiba, S., Aftab, A., Shah, A. K., \& Firoz, A. (2015). Essential oils used in aromatherapy: A systemic review. Asian Pacific Journal of Tropical Biomedicine; 5(8): 601-611.

Bajera, T., Silha, D., Ventura, K. and Bajerov, P. (2017). Composition and antimicrobial activity of the essential oil, distilled aromatic water and herbal infusion from Epilobium parviflorum Schreb. Indian Crops Production, 100, 95-105.

Ceylan, O., Aysel, U., Nurdan, S., \& Mehtap, D. S. (2014). The antimicrobial and antibiofilm activities of Mentha $x$ piperita $\mathrm{L}$. essential oil. Journal of BioSciences and Biotechnology, 2, 2327.

Costa, D. C., Costa, H. S., Albuquerque, T. G., Ramos, F., Castilho, M. C., \& anches-Silva, A. (2015). Advances in phenolic compounds analysis of aromatic plants and their potential applications. Trends in Food Science and Technology; 45, 336-354.

de Aguiar, F. C., Solarte, A. L., \& Tarradas, C. (2018). Antimicrobial activity of selected essential oils against Streptococcus suis isolated from pigs. Microbiology Open, e613.

De Sousa, B., A., de Morais, S. M., Ferreira, P. A. T., Vieira, Í. G. P., Craveiro, A. A., de Santos, Fontenelle, R. O., de Menezes, J. E. S. A., da Silva, F. W. F., \& de Sousa, H. A. (2015). Chemical composition and functional properties of essential oils from Mentha species. Indian Crops Production, 76, 557564.

Diao, W. R., Hua, Q. P., Zhang, H., \& Xu, J. G. (2014). Chemical composition, antibacterial activity and mechanism of action of essential oil from seeds of fennel (Foeniculum vulgare Mill). Food Control, 35, 109-116.

El Babili, F., Bouajila, J., Souchard, J. P., Bertrand, C., \& Bellvert, F. (2014). Oregano: chemical analysis and evaluation of its antimalarial, antioxidant, and cytotoxic activities. Journal of Food Sciences, 76, 512-518.

Freires, I. A., Denny, C., Benso, B., de Alencar, S. M., \& Rosalen, P. L. (2015). Antibacterial activity of essential oils and their isolated constituents against cariogenic bacteria: A systematic review. Molecules, 20, 7329-7358.

Government of Kenya (GoK) (2014). Kenya National Bureau of Statistics, Kenya Population and Housing Census. Ministry of Planning and Development. Government printer, Nairobi, Kenya.

Hercules, S., \& Chrissanthy, P. (2017). Antimicrobial Activity of Basil, Oregano, and mint Essential Oils. Journal of Microbiology and Biotechnology, 27(3), 429-438.

Hua, Y., Zhang, J., Kong, W., Zhao, G., \& Yang, M. (2017). Mechanisms of antifungal and anti-aflatoxigenic properties of essential oil derived from turmeric (Curcuma longa L.) on Aspergillus flavus. Food Chemistry, 220, 1-8.

Huang, D. F., Xu, J. G., Liu, J. X., Zhang, H., \& Hu, Q. P. (2014). Chemical constituents, antibacterial activity and mechanism of action of the essential oil from Cinnamomum cassia bark against four food related bacteria. Microbiology, 83, 357-365.

Huerta, B., Barrero-Dominguez, B., Galan-Relano, A., Tarradas, C., Maldonado, A., \& Luque, I. (2016). Essential oils in the control of infections by Staphylococcus xylosus in horses. Journal of Equine Veterinary Science, 38, 19-23.

Knezevic, P., Aleksic, V., Simin, N., Svircev, E., Petrovic, A., \& 
Mimica-Dukic, N. (2016). Antimicrobial activity of Eucalyptus camaldulensis essential oils and their interactions with conventional antimicrobial agents against multi-drug resistant Acinetobacter baumannii. Journal of Ethnopharmacology; 178, 125-136.

Lan, R. X., Li, T. S., \& Kim, I. H. (2016). Effects of essential oils supplementation in different nutrient densities on growth performance, nutrient digestibility, blood characteristics and fecal microbial shedding in weaning pigs. Animal Feed Science and Technology; 214, 77-85.

Lang, G., \& Buchbauer, G. (2012). A review on recent research results (2008-2010) on essential oils as antimicrobials and antifungals. A review. Flavour Fragrance Journal, 27, 13-39.

Martuccia, J. F., Gendeb, L. B., Neiraa, L. M., \& Ruseckaite, R. A. (2015). Oregano and lavender essential oils as antioxidant and antimicrobial additives of biogenic gelatin films. Indian Crops Production, 71, 205-213.

Nikoli'c, M., Jovanovi'c, K. K., Markovi'c, T., Markovi'c, D., Gligorijevi'c, N., Radulovi'c, S., \& Sokovi'c, M. (2014). Chemical composition, antimicrobial, and cytotoxic properties of five Lamiaceae essential oils. Indian Crops Production, 61, 225-232.

Plant, J., \& Stephens, B. (2015). Evaluation of antibacterial activity of a sizable set of essential oils. Medicinal and Aromatic Plants, 4(185), 2167-0412.

Radaelli, M., da Silvaa, B. P., Weidlich, L., Hoehne, L., Flach, A., Mendonc, L. A., da Costa, A., \& Ethur, E. M. (2015). Antimicrobial activities of six essential oils commonly used as condiments in Brazil against Clostridium perfringens. Brazil Journal of Microbiology, 47, 424-430.

Rajinder, S., Muftah, A. M., \& Shushni, A. (2015). Antibacterial and antioxidant activities of Mentha piperita L. Arabian Journal of Chemistry, 8. 322-328.

Sfeir, J., Lefrancois, C., Baudoux, D., Derbre, S., \& Licznar, P. (2014). In vitro antibacterial activity of essential oils against Streptococcus pyogenes. Evidence-Based Complementary and Alternative Medicine, 13, 269-278.
Shaaban, H. A. E., El-Ghorab, A. H., \& Shibamoto, T. (2014). Bioactivity of essential oils and their volatile aroma components: Review. Journal of Essential Oil Research, 24, 203-212.

Si, S., Z. B., Hayate, H., Boulekbache-Makhloufa, L., Rigoub, P., Reminia, H., Adjaouda, A., Khoudjaa, N. K., \& Madani, K. (2016). Essential oils composition, antibacterial and antioxidant activities of hydro distillated extract of Eucalyptus globulus fruits. Indian Crops Production, 89, 167-175.

Sonam, C., Kanika, S., \& Sanjay, G. (2017). Antimicrobial activity of some essential oils-present status and future perspectives. Medicines, 4, 58-79.

Winanda, H., Arinthip, T., Wasu, P., \& Kannika, D. (2016). Actinomycetes from Eucalyptus and their biological activities for controlling Eucalyptus leaf and shoot blight. Microbiological Research, 188, 42-52.

Yang, X. N., Imran, K., I., \& Kang, S. C. (2018). Chemical composition, mechanism of antibacterial action and antioxidant activity of leaf essential oil of Forsythia koreana deciduous shrub. Asian Pacific Journal of Tropical Biomedicine, 8, 694700.

Zaidi, S., \& Dahiya, P. (2015). In vitro antimicrobial activity, phytochemical analysis and total phenolic content of essential oil from Mentha spicata and Mentha piperita. International Food Research Journal, 22(6), 2440-2445.

Zhang, J., Ye, K. P., Zhang, X., Pan, D. D., Sun, Y. Y., \& Cao, J. X. (2017). Antibacterial activity and mechanism of action of black pepper essential oil on meat-borne Escherichia coli. Frontiers in Microbiology, 7, 2094-310.

Zhang, Y., Liu, X., Wang, Y., Jiang, P., \& Quek, S. Y. (2016). Antibacterial activity and mechanism of cinnamon essential oil against Escherichia coli and Staphylococcus aureus. Food Control, 59, 282-289. 